attached to the novel tone by the animal after this drug is injected.

Medical Research Council

B. J. KEY

Neuropharmacology Research Unit,

Department of Experimental Psychiatry,

The Medical School,

Birmingham, 15.

${ }^{1}$ Key, B. J., and Bradley, P. B., Nature, 182, 1517 (1958).

Bradley, P. B., and Hance, A. J., EEG. Clin. Neurophysiol., 9, 19 (1957).

Bradley, P. B., and Key, B. J., EEG. Clin. Neurophysiol., 10, 97 (1958).

Ader, R., and Clink, D. W., J. Pharmacol. Exp. Ther., 121, 144 (1957),

'Bradley, P. B., and Elkes, J., EEG. Clin. Neurophysiol., 5, 451

- Sharpless, S., and Jasper, H., Brain, 79, 655 (1956).

\section{Biological Activity of Some Humic Fractions isolated by means of Partition Chromatography}

Humus has often been said to possess effects on plant growth over and above the value to plants of the plant nutrients it may release during growth.

Attempts have been made by Forsyth ${ }^{1}$ and by Trojanowski ${ }^{2}$ to extract humus and separate the constituents. Forsyth separated the aqueous extract of humus (fulvic acids), and Trojanowski isolated, by means of chromatography, the compounds of a group of hymatomelanic acids (ulmic acids), which have so far been little investigated. Hymatomelanic acids have now been isolated from various peats and composts using Trojanowski's method.

The crude material was freed from bituminous matter with a mixture of benzene and ethanol. Calcium and iron ions were removed by $0.2 \mathrm{~N}$ hydrochloric acid. The material was then extracted with ethanol, and the hymatomelanic acids precipitated from the ethanol extract by calcium acetate at $p H 6 \cdot 8$. The preoipitate was washed with $0.5 \mathrm{~N}$ hydrochloric acid and water, and then dissolved in acetone, the insoluble residue being removed by centrifuging. The acetone solution was transferred to a column of Whatman cellulose powder (30 gm. cellulose in a tube of diameter $3.5 \mathrm{~cm}$ ), saturated with acetone/water (20:1 vol.), and developed with $n$-butanol saturated with water + acetone $(1+1$ vol.). Under ultra-violet light five fluorescent bands were detected. The bands were eluted successively with acetone and water, and the eluates re-chromatographed on Whatman paper No. 1 in order to check their homogeneity. The paper chromatogram was developed with water/saturated $n$-butanol/acetone/ $0.5 N$ hydrochloric acid (12:12:1.5 vol.). The $R_{F}$ values of the spots were $0.53,0.73,0.95$ (for fractions from low peat), and $0.45,0.48,0.53,0.69,0.95$ (for fractions from compost).

The activity of the fractions was determined by the Avena split coleoptile test of Thimann and Schneider ${ }^{3}$. Controls used were: (1) re-distilled water + sodium chloride in the same quantity as used for the preparation of the solutions of hymatomelanic acid fractions, (2) indole-3-acetic acid solution $(0.0025 \mathrm{gm} . / 1,000$ ml.), (3) solutions prepared from the ash of hymatomelanic acid fractions.

A stimulating influence on growth was found in hymatomelanic acid fractions from low peat with $R_{F}$ value 0.53 and 0.95 (concentrations of $0.01 \mathrm{gm}$.) $100 \mathrm{ml}$.) and in fractions obtained from compost with $R_{F}$ values 0.45 (concentration $0.01 \mathrm{gm} . / 100$ ml.), $R_{F} 0.53$ (concentrations $0.03 \mathrm{gm} . / 100 \mathrm{ml}$.) and $R_{F} 0.95$ (concentration $0.09 \mathrm{gm} . / 100 \mathrm{ml}$.). The stimulating influence of these fractions is similar qualitatively to that of indole-3-acetic acid. No free indole compounds were found in the fractions examined. Under these conditions unpurified complexes of hymatomelanic acids did not show any physiological activity. The observed effects could not have been caused by the mineral constituents of the humic preparations.

A possible explanation for the findings seems to be that curvatures of this type are due to inherent differences in the response to humic substances of adjacent layers of tissue.

\section{A. Paszewski \\ J. Trojanowski \\ A. LOBARZEWSKA}

Department of Plant Physiology and Biochemistry,

Maria Curie-Sklodowska University, Lublin.

${ }^{2}$ Forsyth, W. G. C., Biochem. J., 41, 176 (1947).

2 Trojanowski, J., Ann. M. Curie-Sklodowoska Vniv., C, 10, 275 (1957). Thimann, K. V., and Schneider, C. L., Amer. J. Bot., 28, 792 (1939).

\section{HAMATOLOGY}

\section{Age and Molecular Weight of Dextrans, their Coating Effects, and their Interaction with Serum Albumin}

Dextrans coat blood platelets and red cells ${ }^{1}$ and interact with human serum albumin ${ }^{2}$. Recently two new problems have presented themselves. The first is that the interaction of the same sample of dextran with serum albumin appeared to be less after the dextran had been stored at $4^{\circ} \mathrm{C}$. for about four years, and that the interaction of 'Synkol' (a Russian dextran of unknown age) was still less. The second is that, while the coating effects of dextrans of varying molecular weight scarcely varies, the interaction of the higher molecular weight dextrans with serum albumin has not been measured.

Effect of age of dextran on coating. Through the kindness of Dr. Norman Wheeler of the Abbott Co., we have been able to obtain two specimens of a dextran with a molecular weight similar to that of $285 \mathrm{~W} 3 \mathrm{~A}$ of the Commercial Solvents Co. These two samples of dextran, made by the same process, had been stored for 6 and 40 months respectively, and will be referred to as 'new' and 'old' Abbott dextran. Their viscosity relative to that of saline buffered at $p \mathrm{H} 8$ and their coating effect on human platelets and red cells are compared in Table 1 with that produced by 'old' dextran $285 W 3 A$. The viscosities of the new and the old Abbott dextrans are virtually identical, and are about 0.97 times that of old dextran $285 \mathrm{~W} 3 \mathrm{~A}$. The coating effects of the new and the old Abbott dextrans, determined in a vertical electrophoresis cell and expressed as $U / U_{0}$ (see ref. I), are virtually identical, and almost the same as those of $285 \mathrm{~W} 3 \mathrm{~A}$. The coating effects do not seem to depend

\begin{tabular}{|c|c|c|c|}
\hline & $\eta / \eta$ & $\begin{array}{l}\text { Platelets } \\
U / U_{0} \\
\text { (per cent) }\end{array}$ & $\begin{array}{c}\text { Red cells } \\
U / U_{a} \\
\text { (per cent) }\end{array}$ \\
\hline $\begin{array}{l}\text { Abbott new } \\
\text { Abbott old } \\
285 W 3 A\end{array}$ & $\begin{array}{l}1 \cdot 22 \\
1 \cdot 23 \\
1 \cdot 27\end{array}$ & $\begin{array}{l}1 \cdot 31 \pm 2 \cdot 7 \\
1 \cdot 32 \pm 3 \cdot 1 \\
1 \cdot 30 \pm 2 \cdot 4\end{array}$ & $\begin{array}{l}1.09 \pm 1.9 \\
1.09 \pm 1.7 \\
1.09 \pm 1.5\end{array}$ \\
\hline
\end{tabular}

